\title{
Physiotherapeutic intervention on chronic lumbar pain impact in the elderly
}

\author{
Intervenção fisioterapêutica no impacto da dor lombar crônica em idosos
}

Matheus Santos Gomes Jorge ${ }^{1}$, Caroline Zanin², Bruna Knob³ ${ }^{3}$ Lia Mara Wibelinger

DOI 10.5935/1806-0013.20150062

\section{ABSTRACT}

BACKGROUND AND OBJECTIVES: Geriatric population is considerably increasing. However, musculoskeletal disorders, especially chronic low back pain, which is one of the most common complaints during outpatient assistance, seem to grow together with this phenomenon and physiotherapy may be an alternative to treat such pathology. This study aimed at reviewing in the literature information about physiotherapeutic management for chronic low back pain in the elderly.

CONTENTS: Twenty-six articles were selected by means of a query with research keywords in electronic databases Scielo and Pubmed, published in Portuguese and English, using the keywords low back pain (dor lombar), chronic pain (dor crônica), physical therapy specialty (fisioterapia) and aged (idoso), and published between 2006 and 2015.

CONCLUSION: Different physiotherapeutic techniques and resources are effective to manage the impact of low back pain in the elderly, such as kinesiotherapy (especially by means of stabilizing exercises), electrotherapy, hydrotherapy and individual education management.

Keywords: Chronic pain, Elderly, Low back pain, Physiotherapy.

\section{RESUMO}

JUSTIFICATIVA E OBJETIVOS: A população geriátrica vem crescendo consideravelmente nos últimos tempos. Contudo, os distúrbios osteomioarticulares, especialmente a dor lombar crônica, que é uma das queixas mais comuns nos atendimentos ambulatoriais, parecem crescer juntamente com esse fenômeno e a fisioterapia pode servir como alternativa no tratamento dessa doença. O objetivo deste estudo foi revisar na literatura informaçóes a respeito do tratamento fisioterapêutico no impacto da dor lombar crônica em idosos.

1. Universidade de Passo Fundo, Faculdade de Fisioterapia, Bolsista Probic/FAPERGS, Soledade, RS, Brasil.

2. Universidade de Passo Fundo, Faculdade de Fisioterapia, Bolsista Pibic/CNPQ, São Jorge, RS, Brasil.

3. Universidade de Passo Fundo, Faculdade de Fisioterapia, Passo Fundo, RS, Brasil.

Submitted in August 05, 2015.

Accepted for publication in October 20, 2015.

Conflict of interests: none - Sponsoring sources: none.

Correspondence to:

Matheus Santos Gomes Jorge

BR 285 - Sẫo José

99052-900 Passo Fundo, RS, Brasil.

E-mail: mathjorge5@gmail.com

(C) Sociedade Brasileira para o Estudo da Dor
CONTEÚDO: Foram selecionados 26 artigos por meio de uma consulta de indexadores de pesquisa nas bases de dados eletrônicos Scielo e Pubmed publicados nas línguas portuguesa e inglesa partindo dos descritores dor lombar (low back pain), dor crônica (chronic pain), fisioterapia (physical therapy specialty) e idoso (aged), publicados no período de 2006 à 2015.

CONCLUSÃO: Diversas técnicas e recursos fisioterapêuticos atuam com eficiência no tratamento do impacto da dor lombar crônica em idosos, como a cinesioterapia (especialmente por meio de exercícios estabilizadores), a eletroterapia, a hidroterapia e a gestão na educação do indivíduo.

Descritores: Dor crônica, Dor lombar, Fisioterapia, Idoso.

\section{INTRODUCTION}

In Brazil, elderly are individuals aged 60 years or above ${ }^{1}$. In the next 20 years, the number of elderly people may exceed 30 million, corresponding to almost $13 \%$ of future population $^{2}$.

Worldwide, approximately 100 million individuals have chronic musculoskeletal pain (CP), especially the elderly. The planning of public policies, the implementation of preventive programs and its control are needed to promote functionality and quality of life $(\mathrm{QL})^{3}$.

$\mathrm{CP}$ in geriatric population represents almost $60 \%$ of complaints, especially in lumbar and cervical spine ${ }^{4}$ being that in almost $80 \%$ of cases pain persists for at least 2 years ${ }^{5}$.

Among the elderly, predominance of chronic low back pain (CLBP) may reach approximately $70 \%$, being more frequent among females ${ }^{6}$, between 60 and 69 years of age ${ }^{7}$, and in individuals with low school education ${ }^{6}$. CLBP may also be referred in different structures such as lower limbs 9 , causing incapacity for daily life activities (DLA) and major impact on $\mathrm{QL}^{5}$.

Since CLBP restricts and affects DLA, occupational activities, leisure activities, functionality and physical capacity of the elderly, physiotherapy, by means of its different therapeutic resources, aims at providing symptoms relief, at preventing new injuries caused by the disease, in addition to assuring wellbeing and better QL for the geriatric population ${ }^{10}$.

So, this study aimed at addressing physiotherapeutic interventions to improve CLBP in the elderly.

\section{CONTENTS}

This was a literature review where articles indexed in Scielo and Pubmed electronic databases were manually consulted 
from January 2006 to September 2015. Articles were selected as from the descriptor low back pain (dor lombar), crossed with keywords chronic pain (dor crônica), physiotherapy specialty (fisioterapia) and aged (idoso), according to Science Health descriptors (DeCS).

Inclusion criteria were systematic reviews; clinical trials and case studies; articles in Portuguese and English; articles characterizing "CLBP, with emphasis in the elderly", "physiotherapeutic approach for CLBP with emphasis in the geriatric population"; articles evaluating and/or having as one outcome pain, incapacity and/or QL; articles freely available in full in some of mentioned databases.

Exclusion criteria were articles not meeting mentioned criteria, articles addressing non-mechanical and/or acute pain or with a different approach from what had been proposed.

After recruiting studies and their qualitative analysis, data were presented as follows. After an extensive search, 535 articles were found. Their abstracts were read and initially 298 articles were selected for being relevant for the study. After a judicious qualitative analysis, 26 complete articles were selected for meeting inclusion criteria and providing the theoretical support of this study. Among included articles, 5 addressed physiotherapeutic treatment of CLBP in the elderly within required criteria.

Figure 1 shows results of recruited and selected studies for this review.

Among selected studies, two involved electrotherapy, being that one has addressed aerobic exercises; one has involved just LBP management by self-care of the spine; one has involved water intervention by the Tai Chi method; and one has contemplated lumbar stabilization exercises, together with education of the elderly in pain handling. Sample size of included studies has varied from 16 to 200 individuals with CLBP. All studies had comparisons with at least two groups, of which two have used control groups and the others have compared between intervention methods.

Table 1 presents characteristics of recruited studies about physiotherapeutic action on the impact of CLBP in the elderly.

Studies found suggest a limitation of the subject proposed in this review. However, included studies show different physiotherapeutic techniques for CLBP in the elderly, such as, stabilizing exercises, Tai Chi method in the water, electrotherapeutic devices and pain management or education in the daily life of the elderly with CLBP. Such measures were of great interest to decrease pain and control impacts of CLBP in the geriatric population.

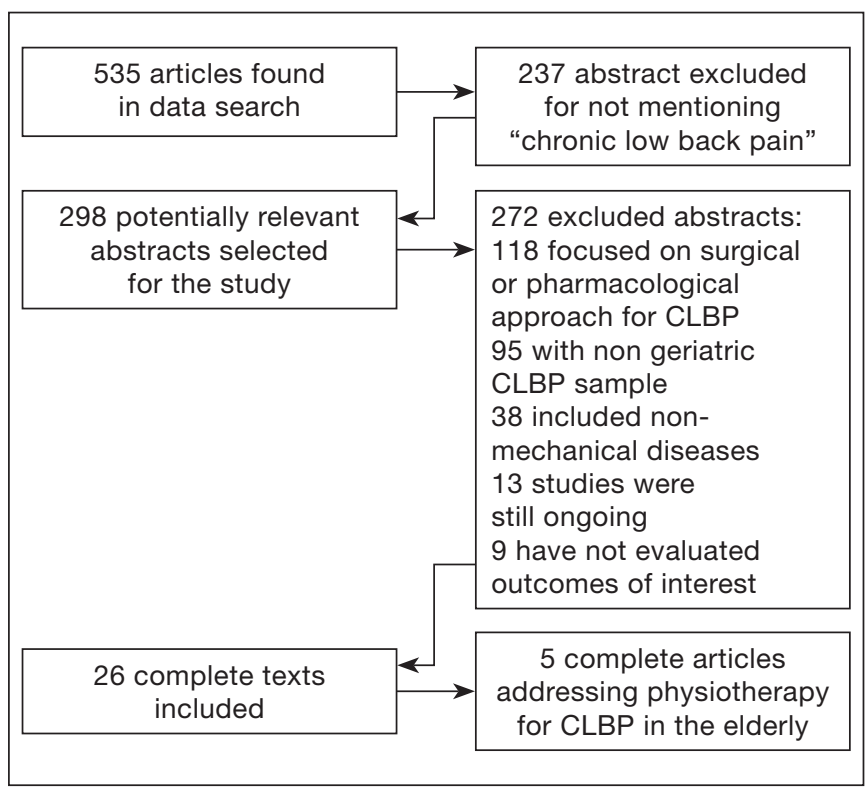

Figure 1. Flowchart of articles selection strategy

CLBP $=$ chronic low back pain.

Table 1. Characterization of studies about physiotherapeutic intervention on chronic low back pain impact in the elderly

\begin{tabular}{|c|c|c|c|}
\hline Authors & Sample & Intervention protocol & Study outcome \\
\hline $\begin{array}{l}\text { Döhnert, } \\
\text { Bauere } \\
\text { Pavão }^{11}\end{array}$ & $\begin{array}{l}28 \text { individuals with CLBP } \\
\text { and aged characteristics }\end{array}$ & $\begin{array}{l}\text { G1: IC (intervention) } \\
\text { G2: TENS (controle) } \\
\text { Time: } 10 \text { sessions ( } 5 \text { weeks) }\end{array}$ & $\begin{array}{l}\text { G1 and G2: } \downarrow \text { pain and incapacity and } \uparrow \text { functionality } \\
\text { No group was better than the other }\end{array}$ \\
\hline Rios et al. ${ }^{12}$ & $\begin{array}{l}30 \text { active elderly with } \\
\text { CLBP }\end{array}$ & $\begin{array}{l}\text { G1: specific spinal self-care booklet and } \\
\text { workshops } \\
\text { G2: without intervention } \\
\text { Time: } 4 \text { weeks }\end{array}$ & $\begin{array}{l}\text { G1: } \downarrow \text { pain, incapacity, n. of painful points aud use } \\
\text { of drugs } \\
\text { G2: without satisfactory results }\end{array}$ \\
\hline Hall et al. ${ }^{13}$ & $\begin{array}{l}160 \text { volunteers aged be- } \\
\text { tween } 18 \text { and } 79 \text { years } \\
\text { with CLBP }\end{array}$ & $\begin{array}{l}\text { G1: Tai Chi exercises in water } \\
\text { G2: routine health care } \\
\text { Time: } 18 \text { sessions ( } 10 \text { weeks) }\end{array}$ & $\begin{array}{l}\text { G1: } \downarrow \text { presence of painful symptoms, pain intensity } \\
\text { and functional incapacity }\end{array}$ \\
\hline Hyoung ${ }^{14}$ & $\begin{array}{l}16 \text { elderly women with } \\
\text { CLBP }\end{array}$ & $\begin{array}{l}\text { G1: LSE + education in pain management } \\
\text { in daily life } \\
\text { G2: without intervention } \\
\text { Time: } 24 \text { sessions ( } 8 \text { weeks) }\end{array}$ & $\begin{array}{l}\text { G1: } \downarrow \text { pain and incapacity, } \uparrow \text { flexibility, satisfaction } \\
\text { with life and MS } \\
\text { G2: without satisfactory results }\end{array}$ \\
\hline Weineret al..$^{15}$ & $\begin{array}{l}200 \text { ederly of both gen- } \\
\text { ders with CLBP }\end{array}$ & $\begin{array}{l}\text { G1: PENS } 30 \mathrm{~min} \\
\text { G2: PENS } 5 \text { min } \\
\text { G3: PENS } 30 \mathrm{~min}+\mathrm{AE} \\
\text { G4: PENS } 5 \text { min }+\mathrm{AE} \\
\text { Time: } 12 \text { sessions ( } 6 \text { weeks })\end{array}$ & $\begin{array}{l}\text { All groups: } \downarrow \text { pain and impact on LBP and DLA; } \uparrow \text { fit- } \\
\text { ness } \\
\text { PENS groups with AE: higher } \downarrow \text { impact of CLBP on } \\
\text { DLA and } \uparrow \text { fitness } \\
\text { PENS groups without AE: higher } \downarrow \text { pain }\end{array}$ \\
\hline
\end{tabular}

$\overline{\mathrm{CLBP}}=$ chronic low back pain; G1 = Group 1; G2 = Group 2; LSE = lumbar stabilization exercise; $\downarrow$ decrease; $\uparrow$ increase; MS = muscle strength; IC $=$ interferential current; TENS = transcutaneous electric nerve stimulation; PENS = percutaneous electric nerve stimulation; $D L A=$ daily life activities; $A E=$ aerobic exercises. 


\section{DISCUSSION}

Our review has found different strategic ways to handle CLBP in the elderly, among them kinesiotherapy, electrotherapy, hydrotherapy and pain control management in daily lives of patients.

Population aging is currently a global phenomenon and studies intend to assure to the geriatric population better QL, evaluating morbidity factors to which the elderly are subject $^{16}$. Among them, there is CP which, added to the fast population aging process, assures to health professionals an increasingly common experience difficult to handle in their daily practice ${ }^{17}$. In the elderly, CP is predominant especially in lumbar spine and lower limbs, being that the higher its intensity the worse the health self-perception of the elderly ${ }^{18}$.

Initially, education of the elderly with CLBP by means of spinal self-care programs is a useful tool for treatment. In addition to allowing better pain control, it decreases incapacity and costs generated by the disease ${ }^{12}$. When this approach is associated to strengthening lumbar region with stabilizing exercises ${ }^{14}$, since the elderly affected by low back pain have further spinal instability ${ }^{19}$, treatment becomes more effective and promising.

Os exercícios de estabilização segmentar promovem contração da musculatura profunda do tronco, principalmente dos músculos transversos do abdômen e multífido. Esses exercícios são eficazes para reduzir a incapacidade e a dor na DLC ${ }^{20}$.

Segmental stabilization exercises promote deep trunk muscles contraction, especially transverse muscles of the abdomen and multifidus. These exercises are effective to decrease CLBP incapacity and pain ${ }^{20}$.

In the elderly, CLBP may be associated to physical incapacity and depression - both as risk factor and as depression as a consequence - which in turn interfere with patients' recov$e^{21}$. So, professionals evaluation should take into consideration such related factors for a more concise approach ${ }^{8}$.

In addition to psychological factors, CLBP in the elderly has been related to decreased physical function, to increased probability of falls, and worse balance due to important postural changes in the geriatric population ${ }^{22}$. A plausible explanation for such could be sarcopenia (loss of muscle mass and strength), commonly associated to the aging process, which may impair functionality and QL of the elderly ${ }^{23}$.

This loss of muscle mass and strength, in addition to reaching peripheral muscles, may also affect deep abdominal muscles and cause lumbar spine instability. So, stabilizing exercises may be indicated as a more effective approach to strengthen such muscles ${ }^{14}$.

There are many reasons for pain in this population, which may be mechanical (where pain increases with movement or load) or non-mechanical (when pain is present at rest) ${ }^{24}$.

Electrotherapy may be a major ally for the treatment of CLBP in the elderly. Treatment modalities, such as interferential current and transcutaneous electric nerve stimulation, provide significant pain and functionality improvement for patients ${ }^{11}$, but electrotherapy should not be used as single therapy.

Percutaneous electric nerve stimulation (PENS) applied for at least 5 minutes and going up to 30 minutes, provides significant pain improvement. When associated to other kinesiotherapeutic strategy, such as aerobic exercises, in addition to decreasing pain, it offers other important benefits for CLPB individuals, such as decreased impact of CLBP on DLA and improved fittness ${ }^{15}$. So, it is believed that treatment based only on electrotherapy is not a satisfactory approach to handle CLBP in the elderly and that there is the need for the association of other physiotherapeutic techniques, especially kinesiotherapy, to treat CLBP in the elderly.

Spinal pain is a major reason for inactivity and difficulty to practice physical activities by the elderly ${ }^{25}$. The level of incapacity is determined by pain location and by different intensities, among other aspects 5 .

Hydrotherapy also seems to be beneficial to treat CLBP, more specifically the Tai Chi method, since it is a safe and effective method for symptomatic treatment of CLBP, decreasing the number of painful points, pain intensity and incapacity caused by the disease ${ }^{13}$.

Our review has observed that long-term physiotherapy has significant effects on CLBP in the elderly. When encouraged to continue with physical exercises after discharge, in addition to improving QL and decreasing the use of continuous drugs, adhesion to treatment by the elderly is significant, which is important to improve functionality ${ }^{26}$.

\section{CONCLUSION}

Physiotherapeutic techniques and resources are effective to treat CLBP in the elderly. It is important to observe that kinesiotherapy is the most indicated intervention, especially by means of stabilizing exercises. Electrothermophototherapeutic measures seem to be interesting for momentary pain relief, but this review stresses that they should not be used as isolated therapeutic approaches. Finally, management and re-education of the elderly should be the first intervention considered to treat CLBP in the elderly.

\section{REFERENCES}

1. WHO) Active Ageing - A Police Framework. A Contribution of the World Health Organization to the second United Nations World Assembly on Aging. Madrid: Spain; April, 2002.

2. Instituto Brasileiro de Geografia e Estatística - IBGE. Perfil dos idosos responsáveis pelos domicílios. Brasília: 2010. [Acesso em: 22 de setembro de 2014]. Disponível em: URL: <http://www.ibge.gov.br/home/presidencia/noticias/25072002pidoso.shtm>.

3. Kayser B, Miotto C, Dal Molin V, Kummer J, Klein SR, Wibelinger LM. Influência da dor crônica na capacidade funcional em idosos. Rev Dor. 2014;15(1):48-50.

4. Celich KL, Galon C. Dor crônica em idosos e sua influência nas atividades da vida diária e convivência social. Rev Bras Geriatr Gerontol. 2009;12(3):345-60.

5. Dellaroza MS, Pimenta CA, Duarte YA, Lebrão ML. [Chronic pain among elderly residentes in Săo Paulo, Brazil: prevalence, characteristics, and association with functional capacity and mobility (SABE Study)]. Cad Saude Publica. 2013;29(2):325-34. Portuguese.

6. Werber A, Zimmermann-Stenzel M, Moradi B, Neubauer E, Schiltenwolf M. Awareness of the German population of common available guidelines of how to cope with lower back pain. Pain Physician. 2014;17(3):217-26.

7. Reis LA, Vasconcelos GT, Reis LA. Caracterizaçâo da dor em pacientes idosos institucionalizados. Arq Neuro Psiquiatr. 2008;66(2):331-5. 
8. Figueiredo VF, Leani SM, Ferreira PH, Pereira AM, Amorim JS. Incapacidade funcional, sintomas depressivos, e dor lombar em idosos. Rev Fisioter Mov. 2013;26(3):549-57.

9. Rudy TE, Weiner DK, Lieber SJ, Slaboda J, Boston JR. The impact of chronic low back pain on older adults: a comparative study of patients and controls. Pain. 2007;131(3):293-301.

10. Silveira MM, Pasqualotti A, Colussi EL, Vidmar MF, Wibelinger LM. Abordagem fisioterápica na dor lombar crônica no idoso. Rev Bras Ciênc Saude. 2010;8(25):56-61.

11. Dohnert MB, Bauer JP, Pavão TS. Study of the effectiveness of interferential current as compared to transcutaneous electrical nerve stimulation in reducing chronic low back pain. Rev Dor. 2015;16(1):27-31.

12. Rios JC, Leite TK, Pereira MM, Sousa FC, Safons MP. Efeitos de um programa educacional de autocuidado da coluna em idosos com dor lombar crônica: um estudo quase-experimental. Motric. 2015;11(1):53-63.

13. Hall AM, Maher CG, Lam P, Ferreira M, Latimer J. Tai chi exercise for treatment of pain and disability in people with persistent low back pain: a randomized controlled trial. Arthritis Care Res. 2011;63(11):1576-83

14. Hyoung HK. Effects of a strengthening program for lower back in older women with chronic low back pain. J Korean Acad Nurs. 2008;38(6):902-13.

15. Weiner DK, Perera S, Rudy TE, Glick RM, Shenoy S, Delitto A. Efficacy of percutaneous electrical nerve stimulation and therapeutic exercise for older adults with chronic low back pain: a randomized controlled trial. Pain. 2008;140(2):344-57.

16. Dellaroza MS, Pimenta CA, Matsuo T. [Prevalence and characterization of chronic pain among the elderly living in the community]. Cad Saude Publica. 2007;23(5):115160. Portuguese.

17. Santos FC, Souza PM, Nogueira SA, Lorenzet IC, Barros BF, Dardin LP. Programa de autogerenciamento da dor crônica no idoso: estudo piloto. Rev Dor. 2011;12(3):209-14.

18. Pereira LV, de Vasconcelos PP, Souza LA, Pereira Gde A, Nakatani AY, Bachion MM.
[Prevalence and intensity of chronic pain and self-perceived health among elderly people: a population-based study]. Rev Lat Am Enfermagem. 2014;22(4):662-9. English, Portuguese, Spanish.

19. Kuo YL, Huang KY, Chiang PT, Lee PY, Tsai YJ. Steadiness of spinal regions during single-leg standing in older adults with and without chronic low back pain. PLoS One. 2015;10(5):e0128318.

20. Ferreira PH, Ferreira ML, Maher CG, Herbert RD, Refshauge K. Specific stabilisation exercise for spinal and pelvic pain: a systematic review. Aust J Physiother 2006;52(2):79-8.

21. Kaptan H, Yalçin ES, Kasimcan O. Correlation of low back pain caused by lumbar spinal stenosis and depression in women: a clinical study. Arch Orthop Trauma Surg. 2012;132(7):963-7.

22. Pereira DS, Argôlo IP, Rosa NM, Felício DC, Queiroz BZ, Silva JP, et al. História de quedas e perfil inflamatório em idosos com dor lombar crônica. Cad Educ Saude Fisioter. 2014;1(1). http://revista.redeunida.org.br/ojs/index.php/cadernos-educacaosaude-fisioterapia/article/view/61.

23. Silva TA, Frisoli Junior A, Pinheiro MM, Szejnfeld VL. Sarcopenia associada ao envelhecimento: aspectos etiológicos e opçóes terapêuticas. Rev Bras Reumatol. 2006;46(6):391-7.

24. Cecchi F, Pasquini G, Paperini A, Boni R, Castagnoli C, Pistritto S, et al. Predictors of response to exercise therapy for chronic low back pain: result of a prospective study with one year follow-up. Eur J Phys Rehabil Med. 2014;50(2):143-51.

25. Krug RR, Lopes MA, Mazo GZ, Marchesan M. Pain impairs the practice of regular physical activities in the perception of longevous women. Rev Dor. 2013;14(3):192-5.

26. Cecchi F, Debolini P, Lova RM, Macchi C, Bandinelli S, Bartali B, et al. Epidemiology of back pain in a representative cohort of Italian persons 65 years of age and older: the InCHIANTI study. Spine. 2006;31(10):1149-55. 